\title{
Dünyada Toplumsal Cinsiyet Karşıtı (Anti-Gender) Hareketler
}

\section{Anti-Gender Movements in the World}

\author{
Dr. Öğr. Üyesi Meryem ŞAHIN (iD) 1
}

\begin{abstract}
$\ddot{\mathbf{O z}}$
Toplumsal cinsiyet, kadın hareketlerinin üzerinde 1 srarla durduğu bir terimdir. $\mathrm{Bu}$ terim cinsiyetin biyolojik tanımının yanı sıra, onu sosyal bir yapı olarak ele almış, kadın ve erkek rollerinin toplumsal bir kurgu olduğunu dile getirmiştir. Yıllar içerisinde terimin kullanım alanı giderek genişlemiş, önemli politik metinlerde kendine yer bulmuş, toplumsal cinsiyet eşitliği uluslararası norm haline gelmiştir. Etki alanındaki bu genişlemeyle birlikte, özellikle 2010 yılından itibaren toplumsal cinsiyete karşı tepkiler de oluşmaya başlamıştır. $\mathrm{Bu}$ çalışmada çeşitli ülkelerde toplumsal cinsiyet bakış açısına ve buna dayalı uygulamalara gösterilen tepkiler ele alınmıştır. Toplumsal cinsiyet karşıtı olarak adlandırılan bu tepkiler Avrupa'dan Latin Amerika'ya kadar pek çok ülkede kendini göstererek geniş çaplı protestolara dönüşmüş, bazı ülkelerde yasal düzenlemelere etkide bulunmuş, toplumsal cinsiyet çalışmalarına sağlanan fonları engelleyebilmiştir. Türkiye'de de son yıllarda benzer tartışmaların tetiklendiği görülmektedir. Toplumsal cinsiyet karşıtı hareketlerde, toplumsal cinsiyet bakış açısının bilimsel değil, ideolojik olduğu vurgulanmakta; bu anlayış aileye, geleceğe ve uygarlığa yönelik tehdit olarak değerlendirilmektedir. Çalışmada toplumsal cinsiyet karşıtı hareketlerin etkili olduğu ülkeler, eylem biçimleri, geliştirdikleri söylemler, etki alanları, bu hareketlere karşı tepkiler ele alınmış ve literatür 1şı̆̆ında tartışılmıştır.
\end{abstract}

Anahtar Kelimeler: Toplumsal cinsiyet, toplumsal cinsiyet karşıtı hareketler, toplumsal cinsiyet ideolojisi, feminizm

Makale Türü: Derleme

\begin{abstract}
Gender is a term that women's movements have insisted on it. This term, in addition to the biological definition of sex, considered it as a social structure and stated that the roles of men and women are social construct. Over the years, the use of the term has expanded, the term has found itself in important political texts and gender equality has become the international norm. With this expansion in the field of influence, especially since 2010, reactions against the gender have started to occur. In this study, the reactions to the perspective of gender in various countries are discussed. These reactions which are called anti-gender movements have become widespread protests in many countries, from Europe to Latin America, have influenced legal regulations in some countries and have been able to block funds for gender studies. Recently, it has triggered a similar debate in Turkey too. The perspective of gender in anti-gender movements is emphasized ideologically, not scientific; this term is considered as a threat to the family, the future and civilization. In this study, the countries where anti-gender movements are effective, their forms of action, their discourses and impacts, the reactions to these movements were discussed.
\end{abstract}

Keywords: Gender, anti-gender movements, gender ideology, feminism

Paper Type: Review

${ }^{1}$ Afyon Kocatepe Üniversitesi, Fen-Edebiyat Fakültesi, Afyon Kocatepe Üniversitesi Kadın ve Aile Araştırmaları Uygulama ve Araştırma Merkezi meryemsahin@aku.edu.tr.

Atıf için (to cite): Şahin, M. (2020). Dünyada toplumsal cinsiyet karşıtı (anti-gender) hareketler. Afyon Kocatepe Üniversitesi Sosyal Bilimler Dergisi, 22(3), 654-670. 


\section{Giriş}

Erkek ve kadın arasındaki ayrım, toplumsal yaşamda evrensel yönü olan örgütleyici bir ilke olarak değerlendirilmektedir (Taylor, Peplau ve Sears, 2012, s. 344). Günümüz literatüründe ise erkek ve kadın arasındaki ayrımlar toplumsal cinsiyet (gender) ve biyolojik cinsiyet (sex) terimleri üzerinden açıklanmakta ve bu iki terimin birbirinden farklı kullanım alanları bulunmaktadır. Feminist hareketin önemli bir terimi olan toplumsal cinsiyet özellikle 1970'lerden sonra yaygın olarak kullanılmaya başlanmış ve çeşitli politik metinlerde kendine yer edinmiştir. Toplumsal cinsiyet kavramını keşfeden kişi John Money olarak bilinmektedir (Goldie, 2014). Terim ilk olarak 1950'lerde Money'in interseks bireyler üzerinde yürüttüğü çalışmalarda kullanılmış (Germon, 2009, s. 23), sonrasında cinsiyet ile toplumsal cinsiyet arasındaki ayrım Psikanalist Stoller'in (1968) yazılarında yer almış, bu çalışmalar Greer, Millett, Oakley, Barrett gibi feminist düşünürlerce benimsenmiştir (Gaten, 1996, s. 6; Stone, 2016, s. 54). 1970'li yıllarda feministlerin yeni bir anlam yükleyerek kullanıma soktuğu (Özkazanç, 2015, s. 109) toplumsal cinsiyet teriminin kullanım alanının genişlemesiyle birlikte çeşitli tartışmalar da başlamış, toplumsal cinsiyet bakış açısı çeşitli yönlerden sorgulanmış ve eleştirilmiştir.

En yaygın kullanılan anlamıyla cinsiyet, kadın ve erkek arasındaki biyolojik farklılıklar olarak ele alınırken; toplumsal cinsiyet cinsel kimliğin toplumsal kurgulanışı olarak değerlendirilmektedir. Cinsiyette biyolojik olarak belirlenmişlik söz konusuyken, toplumsal cinsiyet biyolojiye bağlı değerlendirilmemektedir. Toplumsal cinsiyet toplumda var olan kültürel, ideolojik, dini sistemlerle güçlenen toplumsal bir iş bölümünün yansıması olarak ele alınmaktadır (Ostergaard, 1992; akt. Özçatal, 2011, s. 24). Toplumsal cinsiyet rollerinin kadınlık ve erkekliğe ilişkin durumların belirleyicisi olarak; cinsiyetleri, kimlikleri, aidiyetleri toplumsal süreçte inşa ettiği ve kadınlarla erkeklerin nasıl davranacağını, nasıl hissedeceğini belirlediği düşünülmektedir (Şaşman-Kaylı, 2007, s. 61). Terim kadın ve erkek arasında biyolojik ayrımın yanı sıra toplumlar, kültürler tarafından oluşturulan ayrımlar bulunduğunu, inşa edilen bu ayrımların da çoğunlukla erkekler lehine olduğunu ve kadın-erkek arasında eşitsiz bir ilişkiye hizmet ettiğini vurgulamaktadır. Cinsiyet rollerinin erkekler lehine kurgulandığını varsayan bu açıklamalara paralel bir şekilde, Türkiye'de özellikle kadına yönelik şiddetle ilgili tartışmalarda "erkek egemen yapı" ve "toplumsal cinsiyet eşitliği” söylemleri üzerinden kendini gösteren feminist bir perspektif ön plana çıkmaktadır (Özkazanç, 2015, s. 125). Günümüzde yoğun bir şekilde kullanılmalarına rağmen, cinsiyet ve toplumsal cinsiyet arasındaki ayrımlar tartışmalıdır. Biyolojik olanla toplumsal olanı net olarak ayırmanın çeşitli zorlukları olduğu için feminist literatürde de bu terimlerin nasıl tanımlanacağı konusunda bir uzlaşı yoktur (Özkazanç, 2015, s. 110; Taylor vd., 2012, s. 343).

Toplumsal cinsiyet ve biyolojik cinsiyet ayrımı tartışmalarına zemin olacak şekilde, Foucault doğru ya da gerçek cinsiyet diye bir şeyin gerekli veya zorunlu olup olmadığını sorgulamıştır. Ona göre bedenin kendisi cinsiyetli bir varlık değilken, söylem içinde ve iktidar ilişkileri bağlamında bu anlamı kazanmaktadır (akt. Direk, 2007, ss. 71-72). Butler (2014, ss. 52-54) da benzer şekilde feminist teorinin en önemli yapitlarından sayılan "Cinsiyet Belası" çalışmasında, dişil ve eril olarak heteroseksüel bir biçimde ikiye bölünmüş cinsiyetin, toplumsal cinsiyetlendirme mekanizmalarının temel varsayımı olduğunu, "cinsiyet" denen bu inşanın da toplumsal cinsiyet gibi kültürel bir inşa olduğunu savunmaktadır. Ona göre cinsiyet, tanımı itibariyle aslında hep toplumsal cinsiyettir. Direk'e (2007, s. 73) göre Butler bir anlamda cinsiyet kategorisinin biyolojik, toplumsal cinsiyet kategorisinin ise kültürel olduğu tezini ortadan kaldırmaktadır. Özellikle cinsel fark kavramı üzerine yürüttüğü çalışmalarıyla öne çıkan Braidotti (2019, s. 66) de bedeni büyük oranda inşa edilmiş olan toplumsal ve sembolik kuvvetlerin karmaşık etkileşimi olarak ele almakta, fakat bedeni yalnızca toplumsal pratikler ve söylemlerle değil, bilgi teknolojilerinin etkisi altında, biyoteknoloji ve çağdaş evrimci teoriler 1şı̆̆ında değerlendirmektedir. Ona göre çağdaş bilim ve teknoloji hümanistik düşüncenin ortaya koyduğu sınırları kaldırmış olup, beden kısmen hayvan, kısmen makinedir. Aktarılan 
açıklamalarda görüldüğü gibi, feminist kuramın son 40 yıldaki genel seyri değerlendirildiğinde, bedenin doğrudan kendisinin de tartışmaya açıldığı, bedenin varsayılan doğallığının ve bizzat bedenin kendisinin sorunsallaştırılmaya başlandığ 1 görülmektedir. $\mathrm{Bu}$ tartışmalarda "doğal, biyolojik ya da beden gerçeği”" olmadığı vurgusu giderek artmaktadır (Özkazanç, 2015, s. 110).

Cinsiyet ile toplumsal cinsiyet ayrımındaki belirsizlik ve toplumsal cinsiyet tartışmaları içerisinde giderek bedenin kendisinin de tartışmaya açık hale getirilmesi, toplumsal cinsiyet teriminin kullanım alanlarına ilişkin tartışmaları da beraberinde getirmiştir. Şişman (1996) 1995 yılında Pekin'de gerçekleştirilen BM 4. Dünya Kadın Konferansı'na dair gözlemlerinde, tartışmalı ve önemli konulardan birisinin toplumsal cinsiyet bakış açısı olduğunu, özellikle Müslüman ve Katolik grupların bu terime yönelik eleştiriler getirdiğini aktarmaktadır. Tarihsel olarak değerlendirildiğinde toplumsal cinsiyet teriminin dillendirilmeye başlandığı yıllarda ilk olarak kilise bu terime ilişkin çekincelerini dile getirerek, biyolojik cinsiyet teriminin kullanılmasında ısrar etmiş; kadınlık ve erkekliğin sosyal olarak inşa edilmiş kategoriler olduğu düşüncesine itiraz etmiştir. Vatikan'ın önerisi toplumsal cinsiyet eşitliğinden ziyade eş değerlilik/eşit saygınlık kavramı olmuştur. Bu öneri kadın ve erkek arasındaki cinsel farkları temel alan tamamlayıc1lik teolojisine dayanmaktadır (Kuhar ve Zobec, 2017, s. 33). Kilise bu tutumunu günümüze kadar sürdürmüş, Vatikan (2019) tarafindan cinsiyetlerin Tanrı tarafindan verildiğine vurgu yapan, eğitimde toplumsal cinsiyete yönelik 31 sayfalık rehber kitapçık yayımlamıştır. Bu şekilde cinsiyete yönelik sosyal inşa yaklaşıma karşı tavır alınmıştır.

Kilisenin toplumsal cinsiyet eleştirilerinin dışında, özellikle son yıllarda çok çeşitli çevrelerce eleştiriler, karşı argümanlar oluşturulmaya başlanmış ve bu karşı tepkiler toplumsal cinsiyet karşııı (anti-gender) hareketler olarak adlandırılmıştır. Cinsiyetin sosyal bir yapı olarak kavramsallaştırılmasına karşı çıkan bu hareketler özellikle 2010 yılından itibaren Avrupa ve Latin Amerika başta olmak üzere dünyanın pek çok yerinde ortaya çıkmış, bu ülkelerde kendine özgü hareket alanı edinmiştir. Sokak protestoları, tepki e-postaları, imza kampanyaları gibi aktivist direniş biçimlerinin yanı sıra bilim ve bilgi üretimi de temel mücadele alanı haline gelmiştir. Bu hareketlerin temelinde toplumsal cinsiyet bakış açısının bilimsel değil ideolojik olduğu görüşü yatmaktadır. Toplumsal cinsiyet teorisi (gender theory), toplumsal cinsiyetçilik (genderism) ve toplumsal cinsiyet ideolojisi (gender ideology) olarak kullanılabilen bu terimlerin ortak iddiası, toplumsal cinsiyet anlayışının geleneksel aile ile doğal erkeklik ve kadınlık için bir tehdit oluşturduğudur (Kováts, 2017, s. 175; Squire, 2018, s. 7). Ülkemizde de toplumsal cinsiyet terimine yönelik tepkiler, eleştirel söylemler mevcuttur. Dünyada toplumsal cinsiyet bakış açısı etrafında yürütülen tartışmaların ülkemizde bilinirliğinin artmasının, terim üzerinde yürütülen tartışmaları zenginleştireceği, tartışma ortamına katkı sağlayacağı düşünülmektedir.

\section{Yöntem}

$\mathrm{Bu}$ çalışmada feminizmin önemli kuramsal araçlarından biri olan toplumsal cinsiyet bakış açısına dünyada gösterilen tepkiler ele alınmıştır. Çalışma toplumsal cinsiyet teriminin tarihsel bağlamına veya kavramsal tartışmalara odaklanmayıp, toplumsal cinsiyet bakış açısına yönelik ortaya çıkan tepkileri analiz etme amacıyla sınırlandırılmıştır. Çalışmada öncelikle toplumsal cinsiyet karşıtllğı ile ilgili gelişmekte olan uluslararası literatür, çeşitli sivil toplum kuruluşlarının yayınları ve etkinlikleri, devletlerin resmî belgeleri incelenmiştir. Toplumsal olayların izlenmesinde gazeteler, sürekli yayınlar araştırmacılar için önemli veri kaynakları olarak değerlendirilmektedir. Bu çalışmanın da aktüel ve politik gelişmelerle bağlantılı olması dolayısıyla medya taraması da yapılmış, henüz bilimsel yazında yer bulmayan bilgiler basında çıkan haberler üzerinden ele alınmıştır. Araştırma sonucunda elde edilen bilgilere dayalı olarak öncelikle toplumsal cinsiyet karşıtı hareketlerin etkili olduğu ülkeler ve eylem biçimleri tespit edilmiş, sonrasında bu hareketlerin argümanları ve dünyada bu hareketlere karşı gösterilen tepkiler betimsel bir şekilde sunularak, ilgili literatür ışı̆̆ında tartışılmıştır. 


\section{Toplumsal Cinsiyet Karşıtı Hareketlerin Etkili Olduğu Ülkeler}

Toplumsal cinsiyet karşıtı hareketler özellikle Doğu Avrupa ve Latin Amerika'da etkili olmuş, bununla birlikte Batı Avrupa, ABD, Kanada gibi ülkelerde de ortaya çıkmıştır. Bu gelişmelerle ilgili olarak Kováts ve Poim (2015) editörlüğünde Fransa, Almanya, Macaristan, Polonya, Slovakya'da toplumsal cinsiyet karşıtı hareketlerin ele alındığı çalışma yayımlanmıştır. Benzer şekilde Roman Kuhar ve David Paternotte (2017) editörlüğünde, 11 Avrupa ülkesindeki toplumsal cinsiyet karşıtı hareketliliği anlayabilmek için "Avrupa'da Toplumsal Cinsiyet Karşıtı Kampanyalar (Anti-Gender Campaigns in Europe)" adlı kitap yayımlanmıştır. Kitapta Katolikliğin şekillendirdiği ve hâkim olduğu Avusturya, Fransa, Belçika, İrlanda, İtalya, Macaristan, Hırvatistan, Slovenya, İspanya ve Polonya'dan; Protestan Hristiyanlığın da etkili olduğu Almanya'dan ve Avrupa'nın sınırında olan Rusya'dan örnekler vardır. Bu çalışmalarda toplumsal cinsiyet karşıtı söylemlerin bölgesel farklılıklarına rağmen küreselleştiği dile getirilmektedir (Vieten, 2018, s. 257).

$\mathrm{Bu}$ hareketlerin tepkilerinin merkezinde çoğunlukla okullarda kademeli cinsel eğitim ve toplumsal cinsiyete duyarlı eğitimler verilmesi, eşcinsel evlilikler, eşcinsel çiftlerin üreme-evlat edinme hakları, ulusal ve uluslararası mevzuatlar bulunmaktadır (Kováts, 2017, s. 175; Kuhar ve Paternotte 2017, ss. 1-23; Squire, 2018, s. 6). Özellikle İstanbul'da imzaya açıldığ 1 için "İstanbul Sözleşmesi” olarak da isimlendirilen "Kadına Yönelik Şiddet ve Aile İçi Şiddetin Önlenmesi ve Bunlarla Mücadeleye İlişkin Avrupa Konseyi Sözleşmesi" toplumsal cinsiyet karşıtı hareketler için bir toplanma noktası olmuştur (Squire, 2018, s. 7). Bu sözleşmenin toplumsal cinsiyet karşıtı hareketler için önemli olmasının nedeni toplumsal cinsiyeti tanımlayan ilk uluslararası belge ve toplumsal cinsiyet terimini merkeze alarak hazırlanan bir metin olmasıdır. Sözleşme kadına yönelik şiddeti toplumsal cinsiyet eşitliğini sağlama yoluyla önlemeyi amaçlamaktadır (Resmi Gazete, 2012).

Avrupa Konseyi'ne üye pek çok ülke sözleşmeyi uzun tartışmalardan sonra imzalamış veya reddetmiştir. Özellikle Macaristan, Hırvatistan ve Bulgaristan'da sözleşmeye yönelik sert tepkiler basında geniş yer bulmuştur. Macaristan sözleşmeyi 2014 yılında imzalamış fakat sonrasında onaylamamış, Başbakan Viktor Orban üniversitelerdeki toplumsal cinsiyet çalışmaları programlarını yasakladığını açıklamış (Bianet, 2018), 2020 yılında sözleşmenin reddedilmesine ilişkin siyasi deklarasyonu kabul etmiş̧tir. Bu karşı çıkışın temelinde sözleşmede geçen toplumsal cinsiyet terimine yönelik eleştiriler yatmaktadır. Sözleşmenin reddedilmesine rağmen, kadın ve çocukları şiddetten korumaya yönelik tedbirler yasal sisteme yerleştirilmiştir (Hungary Today, 2020).

Bulgaristan'da İstanbul Sözleşmesi'nin gündem olmaya başlamasından sonra 30 sivil ve dini grubun imzasıyla sözleşme karşıtı bir bildiri hazırlanarak politikacılara gönderilmiş, bildiride sözleşmenin üçüncü cinsiyeti legalleştirebileceği vurgulanmıştır. Bulgaristan Hükümeti 2018 yılında sözleşmeyi reddetmiş, Anayasa Mahkemesi sözleşmenin Bulgaristan Anayasası'na aykırı olduğuna karar vermiştir (Squire, 2018, s. 30). Mahkeme heyetine göre sözleşme cinsiyetin biyolojik ve sosyal boyutunu ayırarak insan türünün iki cinsli olduğu anlayışının dışına çıkmaktadır. Bulgar Ortodoks Kilisesi belgenin onaylanmasına karşı çıkarak, sözleşmenin onaylanmasının manevi ölüm olacağını ileri sürmüş, bu görüşler Bulgaristan Katolik Kilisesi tarafından da kabul edilmiştir (Kırcaali Haber, 2018). Aynı zamanda Bulgaristan Müslümanları Baş Müftülüğü (2018) de yaptığı yazılı açıklamayla sözleşmenin aileyi hedefe koyduğunu ve birtakım riskler barındırdığını belirtmiştir.

Hırvatistan'da 2018 y1lında İstanbul Sözleşmesi önemli bir gündem maddesi olmuştur. İktidar ve solcu-feminist STK'lar sözleşmenin onaylanmasını desteklerken; muhafazakâr muhalefet ve kilise, şiddet ve aile içi şiddete karşı mücadelenin toplum için son derece önemli olduğunu kabul ederken, sözleşmenin "üçüncü cinsiyete" yol açtığını iddia ederek onaylanmasına karşı çıkmış, sözleşmeyi marksist-feminist ideolojinin bir uzantısı olarak

\footnotetext{
${ }^{2}$ Sözleşme adı makalede bundan sonra İstanbul Sözleşmesi olarak kullanılacaktır.
} 
değerlendirmiştir (Croatia, The War, And The Future, 2018). Hırvat muhafazakârlar, parlamentoda onaylanmasına karşı çıktıkları sözleşmenin kadınları koruma argümanı altında toplumsal cinsiyet ideolojisini teşvik ettiğini ve geleneksel aile değerlerini zayıflattı̆̆ını ifade etmiştir (Deutsche Welle, 2018).

Polonya'da toplumsal cinsiyet karşıtı kampanyalar 2012 yılında başlamış (Grzebalska ve Soós, 2016, ss. 9-10), 2014 yılında “toplumsal cinsiyet ideolojisi”ni durdurmaya ilişkin parlamento komisyonu kurulmuştur (Kováts ve Poim, 2015, s. 16). Ülkede yürütülen kampanyalar başlangıçta "toplumsal cinsiyet ideolojisi" taşıyıcısı olarak yorumlanan sözleşmeye karşı koymaya ve sözleşmenin onayını geciktirmeye odaklanmışken, kısa sürede toplumsal cinsiyete ilişkin fonların kesilmesi, eğitimde toplumsal cinsiyet çalışmalarının kaldırılması, transseksüel haklarının veto edilmesi gibi konulara da yayılmıştır (Grzebalska, 2015, ss. 83-103).

Fransa'daki toplumsal cinsiyet karşıtı hareketlerin içerisinde en ön plana çıkan tepki 2013 yılında yaklaşık bir milyon insanın katılımıyla düzenlenen eşcinsel evliliklerin yasallaşmasına karşı düzenlenen protestodur. Protestoda açılan pankartlarda "toplumsal cinsiyeti durdur", "toplumsal cinsiyet ideolojisini durdur" ifadeleri öne çıkmıştır. Bu durum, protestoya katılanların toplumsal cinsiyet bakış açısını ahlaki krizin sembolü olarak değerlendirdiği şeklinde yorumlanmıştır (Brustier, 2015, s. 19; Kuhar ve Zobec, 2017, s. 33). Eşcinsel evliliğe tepki olarak başlayan ve sonrasında toplumsal cinsiyet karşıtlığına dönüşen bu protestolar laiklik ve cinsel özgürlükle anılan bir ülkede sürpriz olarak değerlendirilmiştir (Grzebalska ve Soós 2016, s. 10). Özellikle 2014 seçimleri esnasında toplumsal cinsiyet konusu yoğun bir yer tutmuştur. Fransa'daki sol partiler ise bu güçlü muhafazakâr savunmayla yüzleşmek konusunda stratejik olarak tereddütte kalmış ve toplumsal cinsiyet ideolojisi söylemine çok fazla reaksiyon göstermemişlerdir (Brustier, 2015, ss. 28-35).

Fransa'daki protestoyla aynı dönemde Hırvatistan'da eşcinsel evlilik konusunun referanduma götürülmesi için sivil çağrılar yapılmıştır. İspanya'da ise 2010 yılındaki kürtaja sınırlandırmalar getiren yasa önerisiyle toplumsal cinsiyet karşıtı kampanya tetiklenmiştir. 2012 yılında İspanya Hükümeti kürtaj yasağı taslağını onaylamış, tasarı daha sonra uzlaşma eksikliği nedeniyle geri çekilmiştir. Rusya'da 2013 yılında LGBTQ+ Propaganda Kanunu imzalanmıştır. $\mathrm{Bu}$ kanun, henüz reşit olmayan kişileri geleneksel olmayan cinsel ilişkilerin propagandasına maruz kalmaktan korumayı amaçlamaktadır. Sonrasında yürütülen lobi faaliyetleriyle Belarus, Moldova, Kazakistan, Kırgızistan ve Ukrayna'da benzer yasalar geliştirilmiştir (Grzebalska ve Soós 2016, ss. 9-11).

Slovakya'da, "Toplumsal Cinsiyet Eşitlik Belgesi 2014-2017" ve "Ulusal İnsan Haklarının Korunması ve Geliştirilmesi Stratejisi" adlı Avrupa Birliği belgeleri bir sivil hareketin oluşumuna yol açmış, geleneksel aile modeline yönelik tehditlerle mücadele etmek için "Aile İttifakı" kurulmuştur (Grzebalska ve Soós, 2016, s. 11; Squire, 2018, s. 6). Toplumsal cinsiyet konusu toplumu iki kutba bölmüş, sonuç olarak ülkede 2014 yılında anayasada değişiklik yapılarak eşcinsel evlilik yasaklanmıştır (Durinova, 2015, ss. 104-114). Dünyada toplumsal cinsiyet eşitliğini garanti altına alan ilk ülkelerden biri olan Ukrayna'da "Toplumsal Cinsiyeti Durdur (Stop Gender)" hareketi oluşmuştur. Bu hareket Ukrayna'daki geleneksel aile politikasının, toplumsal cinsiyet politikasına dönüştürüldügünü; bu şekilde liberalizmi teşvik ederek geleneksel aile değerlerinin modasının geçmiş olduğu fikrinin yayıldığını dile getirmektedir. Bu hareket aynı zamanda toplumsal cinsiyet politikalarının tehlikeli olduğunu, çocuk yetiştirme tutumlarından ceza kanunlarının yorumlanmasına kadar vatandaşların yaşantılarının her alanını etkileyeceğini vurgulamaktadır (Hankivsky ve Skoryk, 2014, s. 24). İsveç’te 2018 yılı seçim kampanyasında anti feminist ve toplumsal cinsiyet karşıtı söylem açık bir şekilde yapılmıştır. Öğretmenlerin feminist fikirlerden şiddetli bir şekilde etkilendiği, feminist bir gündem yükleyerek oyuncak arabaları erkek çocuklardan, oyuncak bebekleri kız çocuklardan uzaklaştırdıkları dile getirilmiş; toplumsal cinsiyet farklılıklarının doğal olduğu, 
bunlara meydan okumanın çocukların sağlıklı gelişimine zarar verdiği vurgulanmıştır (Nygren vd., 2018, ss. 4-5).

Latin Amerika'da, özellikle 2016 yılının ikinci yarısında, toplumsal cinsiyeti ideoloji olarak ele alan söylem ağırlık kazanmış ve önemli geliş̧meler yaşanmıştır. İlk tetiklenme 2011 yılında Paraguay'da toplumsal cinsiyet teriminin ulusal eğitim planına girmesine ilişkin tartışmalar esnasında ortaya çıkmıştır. 2013 yılında haftalık TV programlarından birinde Ekvador'un solcu Cumhurbaşkanı Rafael Corrêa, toplumsal cinsiyet bakış açısını bir ideoloji ve aileyi yok etmeye yönelik araç olarak yorumlayarak kınamıştır (Correa vd., 2018). Kolombiya'da eğitim sistemine ilişkin ciddi tartışmalar yaşanmıştır. 2016 yılında on binlerce protestocu Kolombiya Hükümeti'nin toplumsal cinsiyet ideolojisini dayattığını iddia ederek, tepki göstermek için sokağa çıkmış, ardından geleneksel aileyi savunan çok geniş katılımlı ulusal mitingler yapılmıştır. Bu durumun etkisiyle Devlet Başkanı Santos, revize edilmiş eğitim müfredatını geri çekmiştir. Kolombiya'dan sonra Meksika'da da toplumsal cinsiyet ideolojisi söylemiyle benzer mitingler düzenlenmiştir. Geniş katılımlı bu gösteriler, Meksika'nın farklı kentlerinde on binlerce protestocuyu bir araya getirmiş̧tir (Wilkinson, 2017, s. 2).

Feminizm ve queer kuram hakkındaki görüşleriyle tanınan Amerikalı Felsefeci Judith Butler'ın 2017 yılında Brezilya'ya yaptığı ziyaretle Latin Amerika'daki gösteriler doruğa ulaşmış, ülkede pek çok grup bir araya gelerek ziyaretin iptal edilmesine yönelik imza kampanyası başlatmıştır (Correa vd., 2018). Protestocular toplumsal cinsiyet anlayışını ailenin doğal düzeni için bir tehdit olarak gördüklerini vurgularken, kimi akademik çevre ve STK'lar ise ziyarete destek vermiştir (Sexuality Policy Watch, 2018). Bu ziyarete karşı çıkan ve destekleyenler üzerinde yapılan bir araştırmaya göre, Butler'ı destekleyenlerin \% 71'i kendilerini sola ait olarak tanımlarken, ziyareti protesto edenlerin \%60'1 sağ eğilimli olduğunu bildirmiştir (Silva, 2017). Bu protestolar küresel çapta ses getirmiştir. Protestocular tarafindan oluşturulan, ziyaretin iptal edilmesine yönelik talepleri içeren dilekçede, Butler'ın Brezilya'da istenmediği, Brezilyalıların tüm eğitim programlarında toplumsal cinsiyet ideolojisini reddettiği dile getirilmiştir. Aynı zamanda Butler'ın kimliğin değişken ve kültürün bir sonucu olduğunu iddia ettiği ama bilim ve gerçekliğin bunun tersini gösterdiği vurgulanmıştır (Bessa, 2017). Latin Amerika'daki tepkiler kürtajın tamamen yasaklanması, toplumsal cinsiyet ve cinsel yönelim eşitliğine dayalı her türlü kamu politikasının iptal edilmesi yönünde baskı uygulamaktadır (Machado, 2018). Toplumsal cinsiyet ideolojisi söylemi Latin Amerika ile sınırlı kalmamış, ABD ve Kanada'da da giderek artmıştır (Wilkinson, 2017, s. 3).

Çoğu ülkede Türkiye'de olduğu gibi toplumsal cinsiyet eşitliğine yönelik tepkilerin bir mekânı da okullar olmuş, okullarda toplumsal cinsiyet eşitliğinin gündem edilmemesi için çeşitli direnç mekanizmaları oluşturulmuş, okul yöneticileri ve öğretmenlere bask1 uygulanmıştır. Fransa'da ilkokul öğrencileri için izletilen iki erkek balığın âş̧k olduğu animasyon filminin gösterimine karşı bir dilekçe kampanyası başlatılmış (Akt., Kuhar ve Zobec, 2017, s. 37), okul kitaplarındaki toplumsal cinsiyet bakış açısına karşı protestolar düzenlenmiştir (Brustier, 2015, ss. 20-26). İtalya'da ders kitaplarına yönelik tepkiler ortaya çıkmış, bazı devlet ilkokullarında aile çeşitliliğini ele alan kitapların geri çekilmesi sağlanmış (Garbagnoli, 2017, ss. 151-174; Grzebalska, 2016, s. 10); Almanya'da çocukların okulda erken cinselleştirilmesine tepkiler gösterilmiş, Polonya'da cinsel eğitime karşı "Aile Dostu Okul" programı oluşturulmuş; çocukları okul müfredatındaki toplumsal cinsiyet ideolojisinden korumak üzere toplumsal cinsiyet karşıtı eylemler gerçekleştirilmiştir (Grzebalska, 2015, s. 91; Kováts ve Poim, 2015, ss. 15-16; Lavizzari ve Prearo, 2018, s. 2). Eğitim sisteminde toplumsal cinsiyet eşitliğine yönelik tepkiler; cinsel eğitim protestoları, toplumsal cinsiyet ideolojisini teşvik eden kitapları kınamak, çocukları okuldan korumak için toplu protestolar gerçekleştirmek şeklinde kendini göstermiştir (Kuhar ve Zobec, 2017, s. 37).

Toplumsal cinsiyet karşıtı hareketlerin eleştirilerinin merkezinde olan İstanbul Sözleşmesi, Türkiye'nin Avrupa Konseyi dönem başkanlığını yürüttüğü süreçte, İstanbul'da imzalanmış, sözleşmenin ilk imzacısı Türkiye olmuştur. Sözleşmenin gündem olduğu 
dönemlerde parlamentoda herhangi bir muhalefet oluşmamıştır (TBMM Tutanak Dergisi, 2011, s. 109). Türkiye'de İstanbul Sözleşmesi 2011 yılında imzalanarak parlamentoda kabul edilmiş, 2012 yılında resmi gazetede yayımlanmış, 2014 yılında yürürlüğe girmiştir (Resmi Gazete, 2012). Kendini farklı ideolojilerle tanımlayan ve mecliste temsilcisi olan partiler sözleşme konusunda dünyadaki tepkilerin aksine görüş farklılı̆̆ yaşamamıştır. Siyasi uzlaşıyla paralel bir şekilde sivil toplum veya halk nezdinde de o dönemlerde sözleşme tartışma konusu edilmemiş, konunun tartışmaya açıldığ 1 bir zemin oluşmamıştır. Türkiye'de sözleşmenin imzalanma sürecinde tartışmaların olmaması, sözleşmenin ilk imzacısı olduğundan tartışmanın olgunlaşması için yeterli zamana sahip olmadığı şeklinde değerlendirilebilir. Türkiye'de sözleşmenin imzalanma süreci sakin bir atmosferde gerçekleşse de ilerleyen yıllarda karşı hareketler ortaya çıkmaya başlamıştır. İlk olarak Gültekin (2013) tarafından "Ailenin Sonu mu: Aile Politikaları ve İstanbul Sözleşmesi” isimli rapor hazırlanmış, bu raporda özellikle toplumsal cinsiyet eşitliği politikalarının aile politikalarının merkezine yerleştirilmesi eleştirilmiştir. Sonrasında toplumsal cinsiyet bakış açısını eleştirel olarak ele alan araştırmalar yayımlanmıştır (Bkz. Gültekin ve Şahin, 2014; Şahin ve Gültekin, 2013). 2013 tarihinde kurulan Kadın ve Demokrasi Derneği tarafından da toplumsal cinsiyet teriminden ziyade "toplumsal cinsiyet eşitliği”" söylemi eleştirilip, cinsiyetlere özgü konularda adaleti esas alan "toplumsal cinsiyet adaleti" söylemi kullanıma sokulmuştur. Kadın ve Demokrasi Derneği (2015) tarafindan 1. Toplumsal Cinsiyet Adaleti Kongresi düzenlenmiş ve günümüze kadar her yıl farklı temalarla kongre devam ettirilmiştir. 2019 yılına gelene kadar kamuoyu nezdinde çok dikkat çekmeyen toplumsal cinsiyet politikaları, Milli Eğitim Bakanlığı'nca yürütülen "Eğitimde Toplumsal Cinsiyet Eşitliği Projesi (ETCEP)"nin uygulama sürecine dair fotoğrafların basında yer almasıyla kamuoyunun gündemine girmiştir. "Yeniden yazmaya var misın?" sloganıyla toplumsal kadın-erkek rollerinin yeniden yazılmasinı hedefleyen projenin basına yansımasının ardından kamuoyu projeye tepki göstermiş, özellikle sosyal medya üzerinden sivil bir baskı oluşturulmuştur. Bunun üzerine Milli Eğitim Bakanlığı (2019) projenin devam eden değil, tamamlanmış bir proje olduğuna dair açıklama yapmıştır. Bu süreçten sonra muhafazakâr yapısı olan pek çok sivil toplum kuruluşu ve siyasetçi toplumsal cinsiyet eksenli politikalara ve İstanbul Sözleşmesi'ne tepki gösteren basın açıklamaları gerçekleştirmiş, demeçler vermiştir (Bkz. Diyanet-Sen, 2020; Memur-Sen, 2019; Saadet Partisi, 2019; çeşitli illerin STK Platformları). Yönetici kadroların yaklaşımlarında da zaman zaman toplumsal cinsiyet bakış açısına ve İstanbul Sözleşmesi'ne mesafeli duran söylemler yer almıştır.

Latin Amerika, Avrupa ve Türkiye'de toplumsal cinsiyet karşıtı hareketler hâlen devam etmektedir. Dünyada ortaya çıkan tepkiler değerlendirildiğinde toplumsal cinsiyetin farklı başlıkları içeren bir buluşma noktası haline geldiği görülmektedir. Protestolarda cinsiyet rolleri, cinsel yönelim, eşcinsel evlilikler, eşcinsellerin üreme ve evlat edinme hakları, kürtaj, çocukların okulda erken cinselleştirilmesi, eğitim sisteminde cinselliğin ele alınışı, ailenin korunması gibi birbiriyle doğrudan ilgisi olmayan fakat "cinsellik" teması altında bir araya gelebilecek pek çok farklı konu tartışılmaktadır. Tartışılan konuların genel olarak cinsel devrim olarak adlandırılan gelişmelere karşıt olarak konumlandığı görülmektedir. Cinsel devrim, batıda 1950'lerin ortasında başlayıp 1960'larda belirginlik kazanan cinsellik siyaseti olarak ele alınır. Genel olarak bu siyaset cinselliğin evliliğe, tek eşliliğe, heteroseksüelliğe ve üremeye indirgenmesine karş1 çıkar (Şişman, 2015, s. 135), cinsel özgürlük konusunda haz ve istek üzerine her eylemi meşru görür (Yıldırım, 2018, 64). Cinsel devrim ve kadın özgürlük hareketi paralel hareketler olarak değerlendirilmektedir. Cinselliğe dair her şeyin tartış1lması cinsel devrim kadar feminizmin de amacıdır (Şişman, 2013, s. 89). Bu anlamda toplumsal cinsiyet terimi şemsiye terim görevi görerek cinsellikle ilgili geniş bir bağlamda ele alınmış, konu ile ilgili zengin bir tartışma zemini oluşmuştur.

Toplumsal cinsiyet karşıtı hareketlerin söylem aralığı kadar, etkin olduğu coğrafya da geniştir. Bu hareketler Batı Avrupa, Doğu Avrupa, Latin Amerika gibi farklı kültürel özelliklere sahip coğrafyalarda var olabilmiştir. Geniş kesimler toplumsal cinsiyet bakış açısına ilişkin çekincelerini, kaygılarını, eleştirilerini dile getirerek terimi tartışmaya açmış; bu bakış açısının 
geçerliliği sorgulanabilir hale gelmiştir. Türkiye'de toplumsal cinsiyet karşıtı hareketlere getirilen eleştirilerde kadına yönelik şiddet vurgusunun ön planda olduğu görülmektedir. $\mathrm{Bu}$ açıdan Türkiye'de tartışmanın ana zemininin oturmadığından söz etmek mümkündür. Pek çok Avrupa ülkesinde kadına yönelik şiddet, cinayet ve tecavüz oranlarının yüksekliğine rağmen (Uluslararası Af Örgütü, 2019; DSÖ, 2013), tartışmalarda kadına yönelik şiddet vurgusunun olmadığ1 görülmektedir. Toplumsal cinsiyet karşıtı hareketlerde kadına yönelik şiddet savunulan veya meşrulaştırılan bir konu değildir. Daha ziyade toplumsal cinsiyet bakış açısının içeriği, felsefesi, eğitim sistemine, kanunlara, aileye ve geleceğe yansımaları ele alınmakta, neoliberal politikalara karşı da bir muhalefet zemini oluşmaktadır. Bununla birlikte dünyadaki tartışmalarda eşcinsel evliliklerin önemli bir yer tuttuğu görülmektedir. Ülkemizde yasal olarak böyle bir gündem olmadığ 1 için de benzer tartışmaların tetiklenmediğinden bahsedilebilir.

\section{Toplumsal Cinsiyet Karşıtı Hareketlerin Argümanları}

Toplumsal cinsiyet karşıtı hareketler evlilik ve aileyi koruma amaciyla giderek daha fazla uluslararası iş birliği yapmaktadırlar (Graff ve Korolczuk, 2018, s. 799). Bu iş birliğinin bir sonucu olarak da toplumsal cinsiyet karşıtlı̆̆ında farklı ülkelerin benzer argümanlar kullandığ 1 görülmektedir. Toplumsal cinsiyet karşıtı hareketler, en temelde toplumsal cinsiyet bakış açısının ideolojik arka plana sahip olduğunu düşünmektedir. Geleneksel muhafazakâr ve dini değerlere karşı tehdit olarak görülen toplumsal cinsiyet anlayışına karşı, "toplumsal cinsiyet ideolojisi" terimi üretilmiştir. "Toplumsal cinsiyet ideolojisi" terimi toplumsal cinsiyetle ilgili politikalara, toplumsal cinsiyete ilişkin sosyal yapılandırmacılığa karşıt olarak kullanılmaktadır (Squire, 2018, s. 1). Bu ideoloji; geleneksel aile, doğal erkeklik ve kadınlık için tehdit olarak açıklanmakta, toplumsal cinsiyet ideolojisinin kültürel devrimi hedeflediği iddia edilmektedir (Kuhar ve Zobec, 2017, s. 34). Toplumsal cinsiyet karşıtı hareketler toplumsal cinsiyet ideolojisinin asıl hedefinin kadın ve erkek arasındaki doğal, biyolojik cinsel farklılıkların yok edilmesi olduğunu iddia etmektedir. Bu durum da toplumun feminizasyonu, erkekliğin sonlanmas1, ailelerin tahrip olması, demografinin değişimi ve Hristiyanlığın tahrip olmasına neden olacaktır. Bu şekilde ele alınan toplumsal cinsiyet terimi gizli gündemi olan bir truva atı olarak değerlendirilmektedir (Brustier, 2015, s. 20; Felix, 2015, s. 75).

Toplumsal cinsiyet teorisi kadın ve erkek arasındaki biyolojik farklılıkların reddedildiği, cinsiyet akışkanlığının desteklendiği kültürel bir devrimi amaçlayan komplo teorisi ile eş anlamlı değerlendirilmekte, bu teorinin ikili cinsiyet sisteminin ötesine geçerek cinsiyet sonrası toplum oluşturmak için stratejik bir araç olarak kullanıldığı düşünülmektedir. $\mathrm{Bu}$ nedenle toplumsal cinsiyet teorisi erkeklerin erkeksi, kadınların kadınsı olmadığı, birinin kendi toplumsal cinsiyetini ve cinsel yönelimini seçmekte özgür olduğu bir sosyal mühendislik projesi olarak yorumlanmaktadır (Hodžič ve Bijelić, 2014, s. 6; Kuhar ve Zobec, 2017, s. 34). Toplumsal cinsiyet anlayışı farklı toplumlardaki insanların kültürel özerkliklerini ortadan kaldırmaktan, kadın ve erkek haklarını baltalamaktan sorumlu görülmekte (Vieten, 2018, s. 259), hatta sadece kültüre değil, uygarlığa yönelik de bir tehdit olarak ele alınmaktadır.

Toplumsal cinsiyet karşı1t hareketler, toplumsal cinsiyet teorisinin tutarlı, bilimsel bir teori olmadığını iddia etmektedirler. Özellikle toplumsal cinsiyetle ilgili akademik çalışmaların meşruiyeti üzerinde bir mücadele yürütülmektedir. Toplumsal cinsiyet çalışmaları akademik olmamakla, ideolojik olmakla ve tartışmasız biyolojik bulgularla çelişme iddiasıyla eleştirilmektedir. $\mathrm{Bu}$ nedenle toplumsal cinsiyet karşıtı hareketler alternatif bilgi üretme motivasyonuna sahiptir (Kuhar ve Zobec, 2017, s. 36; Pető, 2016, s. 298). Bu karşıt hareketler, dini söylemlerin dışında bilimsel yaklaşımlar ve hak odaklı söylemler inşa etmekte, kürtaj meselesi, geleneksel değerlerin ve doğal ailenin korunması insan hakları bağlamında ele alınmaktadır (Machado, 2018; Wilkinson, 2017, s. 3). Ulusal eğitim müfredatlarına yönelik mücadelede ailelerin çocuğunu kendi ahlaki ve dini inancına göre yetiştirme hakkı, ifade özgürlüğü, din özgürlüğü argümanları kullanılmaktadır (Machado, 2018). Toplumsal cinsiyet karşıtı hareketlerin bilimsel delil kullanma ve hak odaklı söylem geliştirmesi paradigma değişikliği olarak yorumlanmaktadır. 
Bulgaristan'daki İstanbul Sözleşmesi karşıtı kampanyaların metinlerinin analiz edildiği bir araştırmada, sözleşmeye karşı çıkanların kullandığı tespit edilen bazı argümanlar şu şekildedir: Toplumsal cinsiyet bir ideolojidir ve gizli bir ajandaya sahiptir; toplumsal cinsiyet kimliği geleneksel aile değerleri, doğal aile, ebeveyn hakları, heteroseksüel evlilikleri tehdit etmektedir, toplumsal cinsiyet üçüncü cinsiyetin yasallaşmasına neden olacaktır; sözleşmedeki toplumsal cinsiyet tanımı yaratıcının düzenine aykırıdır, çünkü Tanrı insanı kadın ve erkek olarak yaratmıştır; sözleşme ulusal egemenliği baltalamaktadır, anayasaya aykırıdır, aynı zamanda Avrupa müdahalesidir; sözleşmede yer alan GREVIO polis rolündedir. Bu görüşler muhafazakâr sivil toplum kuruluşları, Bulgaristan Ortodoks Kilisesi ve milliyetçi politikacilar tarafından paylaşılmaktadır (Squire, 2018, s. 32).

Toplumsal cinsiyet karşıtı söylemleri ile tanınan Sosyolog Kuby'nin (2014) temel argümanları günümüzde radikal feminist hareket ve eşcinsel hareketlerin birleşerek toplumsal cinsiyet ideolojisini doğurduğu, insan varoluşunun köklerine saldıran antropolojik bir devrim ile karşı karşıya kalındığıdır. Kadın hareketinin önemli kuramsal araçlarından biri olarak değerlendirilen toplumsal cinsiyet terimi, 1980'lerden itibaren politik belgelerde yer alarak uluslararası norm haline gelmiştir (İçli, 2017, ss. 135-136). Kuby (2014) bu gelişmeleri sadece bir kültür yan ürünü değil, proje olarak gördüğünü ifade etmektedir. Ona göre Birleşmiş Milletler ve Avrupa Birliği, planlı bir şekilde feminist ve eşcinsel gündemi dünyadaki her ülkeye toplumsal cinsiyetin yaygınlaşması ve LGBT hakları politikası yoluyla dayatmaya çalışmakta; üye ülkelere sadece yeni ekonomik imkânlar sağlamakla kalmayıp, aynı zamanda ülkelerin kendi değer sistemlerinin de zorla yıkılmasına neden olmaktadır.

Toplumsal cinsiyet karşıtı hareketlerin en önemli hedeflerinden biri olan eğitimde toplumsal cinsiyet politikalarına karşı çıkılmasına ilişkin argümanları; toplumsal cinsiyet ideolojisinin devlet okullarına sızdığı, bu şekilde öğrencilerin cinselleştirildiği, radikal feminist ideoloji ve eşcinsellik propagandasıyla beyinlerinin yıkandığıdır. Ebeveynler çocuklarını kendi dini ve felsefi inançlarına göre yetiştirme haklarının ihlal edildiğini dile getirmektedir (Blum, 2015, ss. 47-48; Brustier, 2015, s. 32; Grzebalska, 2015, ss. 82-87).

Bazı araştırmacılar konuyu uluslararası ilişkiler bağlamında ele almaktadır. Moss (2017, s. 195) Rusya'nın toplumsal cinsiyet karşıtı tutumunu, çökmekte olan liberal Batı'ya karşı muhalefetinin bir ifadesi olarak değerlendirmekte; toplumsal cinsiyet karşıtı söylemleri uluslararası statü kazanmak ve nihayetinde Avrupa Birliği'ni istikrarsızlaştırmak için strateji olarak kullandığını dile getirmektedir. Rusya'daki kampanyaların, Rus Ortodoks Kilisesi'nin desteğiyle doğrudan Kremlin'den üretildiği iddia edilmekte, bu hareketlerin "ulusal egemenlik" ve "geleneksel değerler" savunmasıyla Rusya'nın uluslararası statüsünü yeniden kazanmayı hedeflediği dile getirilmektedir (Correa vd., 2018). Özellikle Doğu Avrupa'da toplumsal cinsiyet bakış açısı, genellikle batının neo-sömürge projesi, yeni bir totaliter ideoloji olarak değerlendirilmektedir (Madarova, 2015, s. 40).

Tüm kavramların yapısöküme uğratılabileceğini ortaya koyan postmodern düşüncenin etkisiyle, cinsiyetle ilgili tüm kavramların da sorgulanması ve bunların hepsinin kültürel yani kurgulanabilir olduğu iddiası yeni bir inşa sürecini doğurmuştur. Sosyal hayata önemli yansımaları olan cinsiyet konusunda özcü yaklaşımı dışarıda bırakan bu seküler dil, toplumsal cinsiyet özelinde kendini bir tartışma içerisinde bulmuştur. Konunun hâkim literatürde seküler dilin dışında ele alınmamasının bir sonucu olarak da güncel tartışmanın baskın tarafını muhafazakâr çevreler oluşturmaktadır. Bununla birlikte toplumsal cinsiyet karşıtı hareketlerin sadece muhafazakâr çevrelerle sınırlı olmadığı, aynı zamanda yeni örgütlenme biçimlerinin de tezahürü olduğu görülmektedir (Kuhar ve Zobec, 2017, s.3). Toplumsal cinsiyet karşıtlarının bazıları farklı kiliselere bağlıyken, bazıları güçlü inananlar olmamasına rağmen anti-liberal söylemlerle bu pozisyondadır. Sosyal düzen isteyen orta sınıf aktivistler, seküler aktörler de bu hareketler içerisinde yer alabilmektedir (Correa vd., 2018; Graff ve Korolczuk, 2018, ss. 798799; Petö, 2016, s. 297). İnananlar, ateistler, Katolikler, Rus Ortodokslar, Latin Amerika Evanjelistleri, Modern Roma Katolikliği tarafından benzer söylemler paylaşılmaktadır. Bu 
durum neoliberal düzenin reddedilmesinde toplumsal cinsiyetin șemsiye bir terim haline gelerek, sembolik bir tutkal görevi gördüğü şeklinde yorumlanmıştır (Brustier, 2015, s. 32; Felix, 2015, s. 75; Grzebalska, Kováts ve Petö, 2017; Pető, 2015, s. 126). Toplumsal cinsiyet karşıtı söylemler aynı zamanda Doğu Avrupa ve Latin Amerika'daki komünizm karşıtı duyguları körüklemektedir (Correa vd., 2018). Bazı Katolik entelektüeller toplumsal cinsiyeti Marksist ideolojinin uzantısı olarak görmekte, savaşın artık işçi sınıfına karşı sermaye arasında değil, kadın ve erkek arasındaki ilişkide yapılandırıldığını dile getirmektedir (akt. Anic, 2015, s. 16; akt. Kuhar ve Zobec, 2017, s. 34).

Toplumsal cinsiyet karşıtı argümanlarda kadına yönelik şiddet önemsizleştirilip meşrulaştııılmamış, kadının çalışma hayatına katılımı hedef alınmamış, buna benzer gündemler oluşturulmamıştır. Çoğu çalışmada toplumsal cinsiyet bakış açısının hem erkekliği hem de kadınlığı yok etmeyi, erkeklerin ve kadınların doğal tamamlayıcılığının ötesine geçmeyi ve dolayısıyla doğal aileyi yok etmeyi hedeflediği üzerine yoğunlaşılmaktadır. Toplumsal cinsiyete karşı geliştirilen argümanların sadece toplumsal cinsiyet eleştirisiyle sınırlı kalmadığı, feminizmin genel söylemlerine karşı da direnç oluşturulduğu görülmektedir. Ailenin korunması, kadın-erkek rolleri, heteroseksüellik savunusu, kürtaj karşıtlığ gibi konular bu duruma örnek gösterilebilir. Nitekim 1970 sonrası feminist harekette sadece kadın ve erkeğin toplumsal rollerinin değil, doğrudan cinselliğin kendisinin de tanıma ve tartışmaya açık hale geldiği görülmektedir. $\mathrm{Bu}$ tartışmalarda bizzat heteroseksüel ilişkinin kadınların ezilmesine, yani ataerkil sisteme hizmet ettiği vurgulanmaktadır. Radikal feminist Millet'e (2011, s. 65) göre ataerkil ideoloji telkininin temelinde aile yer almaktadır. Beauvoir (1986, s. 23) evliliği kadınlar için tehdit olarak değerlendirmiştir. Benzer şekilde Firestone (2013, s. 229; s. 22) aile kurumunun toptan ortadan kaldırılması gerektiğini düşünmekte; üreme araçlarının denetiminin ele geçirilerek, biyolojik aile yerine yapay üremenin yer alması gerektiğini söylemektedir. Feminizmin farklı akımlarının aile kurumuna yönelik eleştirileri farklılaşsa da, tüm feministler aileyi ataerkil yapının temellendiği kurum olarak kabul etmektedir (Şişman, 2013, s. 62). Dolayısıyla feminizmin önemli araçlarından biri olan toplumsal cinsiyet terimi de en fazla "ailenin korunması" argümanı üzerinden eleştirilmektedir.

\section{Toplumsal Cinsiyet Karşıtı Hareketlere Karşı Tepkiler}

Toplumsal cinsiyet savunusu yapan akademisyen ve aktivistler, toplumsal cinsiyet karşıtı kampanyaların başlangıcından beri çok şey elde ettiklerini, geniş kitleleri harekete geçirebildiklerini, pek çok yasanın onayını engellemeyi başardıklarını, bazı ülkelerde devletin sağladığı fonların kesildiğini dile getirmektedir. Bu durum toplumsal cinsiyet savunusu yapan çevreleri harekete geçmeye zorlamıştır. Bu amaçla akademisyenler tarafından toplumsal cinsiyet karşıtı hareket ve kampanyaların sınır ötesiyle paylaştıkları söylemleri, stratejileri ve eylem biçimleri araştırılmaya başlanmış (Grzebalska, 2016; Heinrich Böll Foundation, 2015, 47; Hodžič ve Bijelić, 2014, s. 4; Squire, 2018, s. 6), pek çok ülkede sivil toplum kuruluşları veya üniversite eliyle toplumsal cinsiyet karşıtı hareketleri ele alan konferanslar, çalıştaylar düzenlenmiş, yeni söylemler üretme yönünde çağrılar yapılmaya başlanmıştır. Aşağıda bu çalışmalardan bazı örnekler aktarılacaktır.

2014 yılında Berlin'de Heinrich Böll Vakfı tarafından toplumsal cinsiyet eşitliğine karşı oluşan direncin üstesinden gelebilecek stratejileri tartışmak için 3. Uluslararası Toplumsal Cinsiyet Atölyesi düzenlenmiş, atölyeye Ermenistan, Belarus, Çek Cumhuriyeti, Gürcistan, Macaristan, Polonya, Rusya, Sirbistan, Slovakya ve Ukrayna'dan aktivistler ve akademisyenler katılmıştır. Çalışmada son yıllarda dünyanın her yerinde toplumsal cinsiyet eşitliği ve LGBTIQQ+ haklarının desteklenmesinde düşüşler ve onlara karşı saldırılarda artış olduğu vurgulanmıştır. Çalıştay sonrası “Toplumsal Cinsiyet Karşıtı Hareketler Yükselişte Mi?” isimli rapor yayımlanmış, raporda uzman görüşlerine yer verilmiştir. Yayımlanan raporda toplumsal cinsiyet karşıtı söylemleri çürütmenin yeterli olmadığı, güçlü ve çekici yanıtlara ihtiyaç duyulduğu, yaşam tarzları ne olursa olsun tüm vatandaşlara hitap etmek gerektiği vurgulanmıştır (Heinrich Böll Foundation, 2015, s. 10). 
2016 y1lında Utrecht/Hollanda'da gerçekleștirilen Toplumsal Cinsiyet Bahar Konferansı'ndaki atölye/panel başlıklarından birisi de "Toplumsal Cinsiyet İdeolojisi Savaşına Karşı Organize Olma: LGBTQ+ ve Feminist Hareketler, Mekanlar ve Stratejiler"dir. Davet metninde cinsiyetçilik ve cinsiyet kalıpyargılarına karşı koymayı amaçlayan LGBTQ+ haklarına karşı toplumsal hareketlerde artış olduğu, Avrupa'daki hareketlerin toplumsal cinsiyeti ABD'den gelen kültürel emperyalizm örneği ve geleneksel aile ve toplumsal cinsiyet rollerini tehlikeye sokan ahlaki bir çöküş olarak gördükleri ifade edilmiştir. Aynı zamanda bu hareketlerin çeşitli şekillerde mobilize oldukları belirtilmiştir. Atölye/panelde hem sivil toplum yapılanmasında hem de akademik zeminde toplumsal cinsiyet karşıtı hareketlerin etkisinin araştırılacağı ifade edilmiş; toplumsal cinsiyet karşııtı hareketlerin farklı bölgesel ve ulusal ortamlarda ortaya çıkışının nasıl olduğu, bu hareketlerin hangi yerel/uluslararası ağlara dayandığı, hangi söylemleri kullandığı, başka hangi hareketlerle bağlantı kurduğu gibi başlıkların ele alınacağı duyurulmuştur (ATGENDER Spring Conference, 2016).

Çatı LGBTİ örgütü olan Uluslararası Lezbiyen, Gey, Biseksüel, Trans ve İnterseks Derneği (ILGA), 31 Ocak-2 Şubat 2019 tarihlerinde Brüksel'de "Toplumsal Cinsiyet Karşıtı Hareketleri Cevaplama" isimli atölye düzenlemiştir. Atölye duyuru metninde toplumsal cinsiyet karşıtı söylemlerin bağlamlarının, kullanılan stratejilerin ve mesajlarının içeriğinin daha iyi anlaşılması, bu hareketlere cevap vermek için mevcut kaynakların değerlendirilmesi ve ihtiyaçların tespit edilmesi, yeni söylemler geliştirme ve bunları test etme konularında çalışmalar yürütüleceği belirtilmiş̧ir. Bu duyuru metninde toplumsal cinsiyet karşıtı hareketler genellikle LGBTI haklarına, üreme haklarına, cinsel eğitime, trans haklarına ve toplumsal cinsiyet çalışmalarına karşı söylemler geliştiren muhafazakâr ve dini güçler koalisyonu olarak ifade edilmiş; bu hareketlerin Avrupa genelinde seçimleri etkilediği, İstanbul Sözleşmesi'nin onaylanmasını engellediği, LGBTI'lere yönelik nefret suçu yasasını engelleme gibi önemli başarılara imza attığ vurgulanmıştır. ILGA duyuru metninde, toplumsal cinsiyet karşıtı hareketlere yönelik etkili bir şekilde cevap vermek için yeni anlatılar geliştirmeye, stratejik düşünme ve planlamaya ihtiyaç duyulduğu belirtilmiştir (ILGA Europe, 2019). Bunların dışında pek çok Avrupa ülkesinde "Toplumsal Cinsiyet Karşıtı Hareketler ile Ne Yapmalıyı??" (Europeum, 2017), "LGBTIQ+ Konuşmaları: Toplumsal Cinsiyet Karşı1tı Hareketlere Nasıl Cevap Verilir?” (SETA, 2019), “Avrupa'da Toplumsal Cinsiyet Karşıtı Hareketler” (Institut du Genre, 2017; University College London, 2019) konulu etkinlikler gerçekleştirilmektedir.

Aktarılan çalışmalarda görüldüğü üzere toplumsal cinsiyet karşıtı hareketlerde olduğu gibi, toplumsal cinsiyet savunusu yapmayı amaçlayan çalışmalar da LGBTI haklarından bağımsız ele alınmamakta, LGBTI hakları ve toplumsal cinsiyet aynı zeminde tartışılmaktadır. Bu açıdan kadın hakları söylemi ile eşcinsel hakları söyleminin iç içe geçtiği yorumunu yapmak mümkündür.

Toplumsal cinsiyet karşıtı hareketlere yönelik ortaya çıkan çalışmalarda toplumsal cinsiyet karşıtı hareketlerin söylemlerinin analiz edildiği, karşıt hareketlerin elde ettiği kazanımlara karşı yeni strateji geliştirme ihtiyacının vurgulandığ 1 , toplumsal cinsiyet savunusundaki mevcut söylemlerin artık yeterli olmadığı, bilimsel ve kültürel olarak uluslararası düzeyde sorgulandığının kabul edildiği görülmektedir. Bu hareketlere yönelik olarak yeni stratejiler tartışılmakta ve planlanmaktadır. Bu çalışmalar terim üzerinde yürütülen tartışmaların içeriğinin zenginleşmesi adına olumlu gelişmeler olarak değerlendirilebilir. Toplumsal cinsiyet karşıtlarının getirdikleri eleştiriler, terim üzerinde daha derinlikli çalışma yapılmasına olanak sağlamıştır. Bu açıdan toplumsal cinsiyet literatürünün canlılığını koruyan, aktif bir çalışma alanı olduğu söylenebilir.

\section{Tartıșma, Sonuç ve Öneriler}

Erkek ve kadınlar arasındaki ilişkilerin dönüştürülmesini, kadınların çeşitli olanaklara sahip olabilmesi için dünyanın değiştirilmesini amaçlayan feminizm, bu amaçları nedeniyle hem eylemsel hem de ideolojik düşünceler dizisi olarak ele alınmaktadır (Ramazanoğlu, 1998, s. 26). 
$\mathrm{Bu}$ dönüşümü hedefleyen bakış açılarından birisi olan toplumsal cinsiyet, kadın çalışmaları ve feminist kuram için bir temel oluşturmaktadır (Alptekin, 2011, s. 35). Cinsiyetin verili bir özellik olduğu inancının yıkılarak kurgusal ve kültürel bir gerçekliğe indirgendiği toplumsal cinsiyet literatürü, beraberinde bir iktidar alanı olarak bedenin ve cinsiyetin yeniden inşasını getirmiştir. Bu yaklaşıma göre cinsiyet bir inşaysa, yeni kurguların oluşturulması mümkündür (Toprak, 2019, s. 11; Şişman, 2013, s. 45). Bu durum, bir ideoloji olarak da ele alınan feminizmin önemli terimlerinden biri olan toplumsal cinsiyetin de ideolojik mi yoksa bilimsel mi olduğu tartışmalarını beraberinde getirmiş̧ir.

Toplumsal cinsiyet teriminin uluslararası politik metinlerde yer bulması ve bu metinler üzerinden kadın ve erkek rollerine ilişkin evrensel normlar belirlenmesi, özellikle beden politikalarına ilişkin tartışmaları tetiklemiştir. Toplumsal cinsiyet bakış açısının ve feminizmin queer teoriyle olan ilişkisi bağlamında (Özkazanç, 2015; Özkazanç, 2019), eleştirilen sadece kadın ve erkeğin toplumsal rollerinde eşitliğe yönelik politikalar olmamış; eşcinsel evlilikler, eşcinsel çiftlerin üreme ve evlat edinme hakları, çocukların erken cinselleştirilmesi, çocukların okullarda cinsel yönelimleri de içeren toplumsal cinsiyet eğitimlerine tabi tutulmaları Orta ve Doğu Avrupa başta olmak üzere küresel düzeyde tepkiyle karşılanmıştır. Toplumsal cinsiyet karşıtı olarak adlandırılan bu tepkiler sadece duygu dilini esas alan bir korku siyaseti üzerinden konumlanmamış, bilimsel dil de kullanarak güçlü argümanlar ortaya koyabilmeyi başarmıştır. $\mathrm{Bu}$ şekilde geniş kitleleri etki altına alan toplumsal cinsiyet karşıtı hareketlenmeler, toplumsal cinsiyet terimini sorgulamaya açabilmiş, toplumsal etkinin yanı sıra siyasi arenada da etkili olmuştur.

$\mathrm{Bu}$ hareketlenmelerin en önemli özelliklerinden birisi çok farklı kesimleri bir araya getirebilmesidir. Kilisenin büyük desteğini alan bu hareketler, aynı zamanda sekülerler, neoliberal politika karşıtları, farklı din ve mezhep mensupları tarafından da desteklenebilmektedir. Kadın ve erkeğe yönelik oluşturulan yeni tasavvurlar nedeniyle, yeni bir sömürge ideolojisi olarak değerlendirilen toplumsal cinsiyet anlayışı kadın hakları bağlamından ziyade; insanlığa, uygarlığa ve özellikle ailenin geleceğine yönelik bir tehdit şeklinde yorumlanmaktadır.

Toplumsal cinsiyet karşıtı hareketler genel olarak değerlendirildiğinde temelde dört unsur göze çarpmaktadır. İlk olarak, toplumsal cinsiyetin geniş bir bağlamda ele alındığı ve bu kapsamda cinsellikle ilgili pek çok politikanın eleştirildiği görülmektedir. İkincisi, bu hareketler sınırlı bir kültürden ziyade geniş bir coğrafyada ortaya çıkmaktadır. Üçüncüsü, toplumsal cinsiyet karşıtı hareketler toplumun farklı ideolojik görüşlere sahip kesimlerini içeren bir muhalefete sahiptir. Dördüncü unsur ise karşıt olarak üretilen söylemlerin çıkış noktasının çeşitlilik göstermesidir, dini söylemler olduğu kadar seküler dilin de kullanıldığı görülmektedir. Toplumsal cinsiyet teriminin içeriğindeki belirsizliklerin kamuoyu üzerinde çeşitli kaygılara sebep olduğu anlaşılmaktadır. Bu kaygının çok geniş kesimlerde paylaşılması, terimi eleştirel bir dikkatle ele almayı gerekli kılmaktadır.

Şişman'ın $(2013$, s. 95; 2015, s. 101) tespitine göre saf bir teori olarak feminizm dünyada gücünü kaybederken, söylem olarak kitleselleşmektedir. Toplumsal cinsiyet terimi de bu kitleselleşmenin bir örneği olarak değerlendirilebilir. Dünyayla paralel şekilde Türkiye'de toplumsal cinsiyet eşitliği politikaları ana akım politika olarak uygulanmakta, buna karşılık bu politikaları eleştiren kitleler bulunmaktadır. Özellikle son yıllarda aile yapısına ilişkin ortaya çıkan problemlerin artması ile birlikte feminizmin argümanlarına yönelik eleştiriler yapılmaya başlanmış, toplumsal cinsiyet eşitliğinin eğitim politikalarındaki uygulamaları tepkiyle karşılanmıştır. Türkiye'de toplumsal cinsiyet bakış açısına karşı olarak konumlanan argümanlar, kadına şiddet söylemi üzerinden eleştirilmiş; bu indirgemeci yaklaşım nedeniyle kavramsal analizler daha sınırlı düzeyde kalmıştır. Ülkemizde henüz terimin bilimselliğinin, felsefesinin, tarihsel arka planının, beden politikalarının, gelecek tasavvurlarının eleştirel bakışla ele alındığı akademik bir tartışma platformundan söz etmek mümkün değildir. Bu çalışma konunun akademik düzeyde tartışmaya açılmasını amaçlamaktadır. Bu gerçekleştiği takdirde, terim üzerindeki tek yönlü bilgi akışından ziyade, çok sesliliği esas alan tartışma platformları 
oluşacak; toplumsal cinsiyete, kadın sorunlarına dair farklı perspektifler ortaya çıkma imkânı bulacaktır.

Bu çalışma Türkiye'deki toplumsal cinsiyet literatüründe henüz yeterince yer bulamamış bir konu olan toplumsal cinsiyet karşıtı hareketlere odaklanan bir başlangıç olarak düşünülmektedir. Toplumsal cinsiyet karşıtı metinlerin içerik analizinin yapılması, toplumsal cinsiyet karşıtı bireyler ile derinlemesine mülakat ve odak grup görüşmeleri gerçekleştirilmesi, toplumsal cinsiyet karşıtlarının kadın sorunlarına bakış açısının ele alınması gibi farklı yöntem ve içeriklere sahip ileri araştırmalarla bu konudaki literatürün geliştirilmesi önerilmektedir.

\section{Kaynakça}

Alptekin, D. (2011). Sokaktan akademiye: Kadın hareketinin kurumsallaşma süreci. Selçuk Üniversitesi Sosyal Bilimler Enstitüsü Dergisi, 26, 33-43.

Anic, J. R. (2015). Gender, gender 'ideology' and cultural war: Local consequences of a global idea - Croatian example. Feminist Theology, 24(1), 7-22.

ATGENDER Spring Conference (2016). Organizing against the war on "gender ideology": $L G B T Q *$ /Feminist movements, spaces and strategies. https://atgender.eu/wpcontent/uploads/sites/207/2015/12/Conference_6.pdf (Erişim Tarihi: 10.05.2020).

Bağımsız İletişim Ağı (BİANET) (2018). Macaristan'da toplumsal cinsiyet çalışmaları yasaklandl. http://m.bianet.org/kadin/toplumsal-cinsiyet/201954-macaristan-da-toplumsalcinsiyet-calismalari-yasaklandi_(Erişim Tarihi:_10.05.2020).

Beauvoir, S. (1986). Ben bir feministim-Alice Schwarzer'le konuşmalar (Ayşe, Minu, Sedef, Çev.). İstanbul: Kadın Çevresi Yayınları.

Bessa, T. (2017). Judith Butler, "gender ideology" and the rise of conservatism in Brazil. Feminist Academic Collective. https://feministacademiccollective.com/2017/11/17/judithbutler-gender-ideology-and-the-rise-of-conservatism-in-brazil/_(Erişim Tarihi: 10.05.2020).

Blum, A. (2015). Germany. E. Kováts ve M. Poim (Ed.), Gender as symbolic glue: The position and role of conservative and far right parties in the anti-gender mobilizations in Europe içinde (ss.40-61). Budapest: Foundation for European Progressive Studies ve FriedrichEbert-Stiftung.

Braidotti, R. (2019). Kadın-Oluş: Cinsel farkı yeniden düşünmek. İstanbul: Otonom Yayınları.

Brustier, G. (2015). France. E. Kováts ve M. Poim (Ed.), Gender as symbolic glue: The position and role of conservative and far right parties in the anti-gender mobilizations in Europe içinde (ss.19-39). Budapest: Foundation for European Progressive Studies ve Friedrich-Ebert-Stiftung.

Bulgaristan Cumhuriyeti Müslümanlar Diyaneti Baş Müftülüğü (2018). Bulgaristan müslümanlar diyaneti beyannamesi. https://grandmufti.bg/tr/za-nas-5/novini/5249-s-t-a-n-ov-i-sht-e-na-myusyulmansko-izpovedanie-glavno-myuftiistvo-v-republika-balgariya-2.html (Erişim Tarihi: 10.05.2020).

Butler, J. (2014). Cinsiyet belası (B. Ertür, Çev.). İstanbul: Metis Yayınları.

Correa, S. ve diğerleri (2018). The Globalisation of anti-gender campaigns. International Politics and Society. https://www.ips-journal.eu/topics/human-rights/article/show/theglobalisation-of-anti-gender-campaigns-2761/_Erişim Tarihi: 24.06.2019).

Croatia, The War, and the Future (2018). Croatia in throes of marxist-feminism in Istanbul Convention. $\quad$ https://inavukic.com/2018/02/11/croatia-in-throes-of-marxistfeminism-in-istanbul-convention/_(Erişim Tarihi: 10.05.2020). 
Deutsche Welle Türkçe (2018). Hırvatistan'da İstanbul Sözleşmesi tartışllyyor. https://www.dw.com/tr/h\%C4\%B1rvatistanda-istanbul-s\%C3\%B6zle\%C5\%9Fmesi$\operatorname{tart} \% \mathrm{C} 4 \% \mathrm{~B} 1 \% \mathrm{C} 5 \% 9 \mathrm{~F} \% \mathrm{C} 4 \% \mathrm{~B} 11 \% \mathrm{C} 4 \% \mathrm{~B} 1$ yor/a-42949278_(Erişim Tarihi: 10.05.2020).

Direk, Z. (2007). Judith Butler: Toplumsal cinsiyet ve bedenin maddeleşmesi. Z. Direk (Ed.), Cinsiyetli olmak: Sosyal bilimlere feminist bakışlar içinde (ss. 67-84). İstanbul: YKY.

Diyanet-Sen (2020). Türkiye İstanbul Sözleşmesi'nden Çekilmelidir. http://www.diyanetsen.org.tr/turkiye-istanbul-sozlesmesinden-cekilmelidir (Erişim Tarihi: 11.05.2020).

Durinova, P. (2015). Slovakia. E. Kováts ve M. Poim (Ed.), Gender as symbolic glue: The position and role of conservative and far right parties in the anti-gender mobilizations in Europe içinde (ss.104-125). Budapest: Foundation for European Progressive Studies ve Friedrich-Ebert-Stiftung.

Dünya Sağl1k Örgütü (2013)._Global and regional estimates of violence against women: Prevalence and health effects of intimate partner violence and non-partner sexual violence. Switzerland: WHO Press.

Europeum (2017). Invitation: What should we do with anti-gender movements in Europe? http://www.europeum.org/en/articles/detail/1422/invitation-what-should-we-do-with-antigender-movements-in-europe (Erişim Tarihi: 10.05.2020).

Felix, A. (2015). Hungary. E. Kováts ve M. Poim (Ed.), Gender as symbolic glue: The position and role of conservative and far right parties in the anti-gender mobilizations in Europe içinde (ss.62-82). Budapest: Foundation for European Progressive Studies ve FriedrichEbert-Stiftung.

Firestone, S. (2013). Cinselliğin diyalektiği (Y. Salman, Çev.). İstanbul: Payel Yayınevi.

Garbagnoli, S. (2017). Italy as a lighthouse: Anti-Gender protests between the "anthropological question" and national identity. R. Kuhar ve D. Paternotte (Ed.), Anti-Gender campaigns in europe: Mobilizing against equality içinde (ss. 151-174). New York, London: Rowman \& Littlefield International.

Gaten, M. (1996). Imaginary bodies: Ethics, power and corporeality. Londan: Routledge.

Germon, J. (2009). Gender: A genealogy of an idea. New York: Palgrave Macmillan.

Goldie, T. (2014). The man who invented gender: Engaging the ideas of John Money. Vencouver: UBC Press.

Graff, A. ve Korolczuk, E. (2018). Gender as 'ebola from Brussels': The anti-colonial frame and the rise of illiberal populism. Signs Journal of Women in Culture and Society, 43(4), 797-821.

Grzebalska, W. (2015). Poland. E. Kováts ve M. Poim (Ed.), Gender as symbolic glue: The position and role of conservative and far right parties in the anti-gender mobilizations in Europe içinde (ss. 83-103). Budapest: Foundation for European Progressive Studies ve Friedrich-Ebert-Stiftung.

Grzebalska, W. (2016). Why the war on "gender ideology" matters-and not just to feminists: Antigenderism and the crisis of neoliberal democracy. Visegrad Insight. http://visegradinsight.eu/why-the-war-on-gender-ideology-matters-and-not-just-to-feminists/ (Erişim Tarihi: 10.05.2020).

Grzebalska, W. ve Soós, E. (2016). Conservatives vs. the "culture of death": How progressives handled the war on "gender"?. Brussels: FEPS Young Academics Network.

Grzebalska, W., Kováts, E. ve Pető, A. (2017). Gender as symbolic glue: How 'gender' became an umbrella term for the rejection of the (neo)liberal order. Political Critique. 
http://politicalcritique.org/long-read/2017/gender-as-symbolic-glue-how-gender-became-anumbrella-term-for-the-rejection-of-the-neoliberal-order/ (Erişim Tarihi: 10.05.2020).

Gültekin, M. (2013). Aile politikaları ve İstanbul Sözleşmesi. Bursa: Aile Akademisi Derneği. http://aileakademisi.org/sites/default/files/aile_politikalari_ve_istanbul_sozlesmesi_0.pdf (Erişim Tarihi: 10.05.2020).

Gültekin, M. ve Şahin, M. (2014). Türkiye'de ve Dünyada Kadına Şiddet. İstanbul: Sekam Yayınlar1.

Hankivsky, O. ve Skoryk, M. (2014). The current situation and potential responses to movements against gender equality in Ukraine. East/West: Journal of Ukrainian Studies, l(1), 19-43.

Heinrich Böll Foundation (Ed.) (2015). Anti-Gender movements on the rise? Strategising for gender equality in Central and Eastern Europe. Berlin: Heinrich Böll Foundation.

Hodžič, A. ve Bijelić, N. (2014). Neo-Conservative threats to sexual and reproductive health \& rights in the European Union. Zagreb: CESI.

Hungary Today (2020). Parliament adopts declaration rejecting Istanbul Convention. https://hungarytoday.hu/hungary-istanbul-convention-parliament-declaration/ (Erişim Tarihi: 8.05.2020).

ILGA Europe (2019). Workshop: "Responding to the anti-gender movement". https://www.ilga-europe.org/resources/news/latest-news/responding-anti-gender-movementrhetoric-opposition-our-movements (Erişim Tarihi: 10.05.2020).

Institut du Genre (2017). Right-Wing and anti-gender movements in Europe: how gender became a pop-science. http://institut-du-genre.fr/fr/actualites-du-genre/manifestationsscientifiques-138/article/right-wing-and-anti-gender_(Erişim Tarihi: 10.05.2020).

İçli, G. (2018). Toplumsal cinsiyet eşitliği politikaları ve küreselleşme. Pamukkale Üniversitesi Sosyal Bilimler Enstitüsü Dergisi, 30, 133-143.

KADEM (2015). 1. Toplumsal cinsiyet adaleti kongresi. https://kadem.org.tr/toplumsalcinsiyet-adaleti-kongresi-sonuc-bildirgesi/ (Erişim Tarihi: 10.05.2020).

Kurcaali Haber (2018). Meclis, İstanbul Sözleşmesi'ni onaylama sürecini durdurdu. https://kircaalihaber.com/?pid=3\&id_news=20468 (Erişim Tarihi: 10.05.2020).

Kováts, E. (2017). The emergence of powerful anti-gender movements in Europe and the crisis of liberal democracy. M. Kötting vd. (Ed.), Gender and far right politics in Europe içinde (ss. 175-190). Switzerland: Palgrave Macmillan.

Kováts, E. ve Poim, M. (Ed.) (2015). Gender as symbolic glue: The position and role of conservative and far right parties in the anti-gender mobilizations in Europe. Budapest: Foundation for European Progressive Studies and Friedrich-Ebert-Stiftung.

Kuby, G. (2014). Genderism - A new ideology destroying the family. https://www.lifesitenews.com/opinion/genderism-a-new-ideology-destroying-the-family (Erişim Tarihi: 10.05.2020).

Kuhar, R. ve Paternotte, D. (2017). Gender ideology in movement. R.Kuhar ve D. Paternotte (Ed.), Anti-Gender campaigns in Europe: Mobilizing against equality içinde (ss. 1-23). New York, London: Rowman \& Littlefield International.

Kuhar, R. ve Zobec, A. (2017). The anti-gender movement in Europe and the educational process in public schools. CEPS Journal, 7(2), 29-46.

Lavizzari, A. ve Prearo, M. (2018). The anti-gender movement in Italy: Catholic participation between electoral and protest politics. European Societies, DOI: 10.1080/14616696.2018.1536801. 
Machado, M. R. de A. (2018). Conservative mobilization in Latin America and its impacts on women's and adolescents' human rights. Oxford Human Rights Hub. http://ohrh.law.ox.ac.uk/conservative-mobilization-in-latin-america-and-its-impacts-onwomens-and-adolescents-human-rights/_(Erişim Tarihi: 10.05.2020).

Madarova, Z. (2015). Love and fear argumentative strategies against gender equality in Slovakia. Heinrich Böll Foundation (Ed.), Anti-Gender movements on the rise? Strategising for gender equality in Central and Eastern Europe içinde (ss.33-42). Berlin: Heinrich Böll Foundation.

Memur-Sen (2019). Memur-Sen Kadınlar Komisyonundan İstanbul Sözleşmesi Çağrısı. http://www.memursen.org.tr/memur-sen-kadinlar-komisyonundan-istanbul-sozlesmesicagrisi (Erişim Tarihi: 11.05.2020).

Millet, K. (2011). Cinsel politika. (S. Selvi, Çev.). İstanbul: Payel Yayınları.

Milli Eğitim Bakanlığı (2019). Basın açılaması. http://www.meb.gov.tr/basinaciklamasi/haber/17798/tr (Erişim Tarihi: 24.06.2019).

Moss, K. (2017). Russia as the saviour of european civilization: Gender and the geopolitics of traditional values. R. Kuhar ve D. Paternotte (Ed.), Anti-Gender campaigns in Europe: mobilizing against equality içinde (ss.195-214). London: Rowman \& Littlefield International.

Nygren, K., Martinsson, L. ve Mulinari, D. (2018). Gender equality and beyond: At the crossroads of neoliberalism, anti-gender movements, "European" values, and normative reiterations in the Nordic model. Social Inclusion, 6(4), 1-7.

Özçatal, E. Ö. (2011). Ataerkillik, toplumsal cinsiyet ve kadının çalışma yaşamına katılımı. Çankırı Karatekin Üniversitesi İktisadi ve İdari Bilimler Fakültesi Dergisi, 1(1), 21-39.

Özkazanç, A. (2015). Feminizm ve Queer kuram. Ankara: Dipnot Yayınları.

Özkazanç, A. (2019). Toplumsal cinsiyet eşitliği karşıtlığının dinamikleri. https://m.bianet.org/bianet/toplumsal-cinsiyet/206353-toplumsal-cinsiyet-esitligikarsitliginin-dinamikleri (Erişim Tarihi: 10.05.2020).

Petö, A. (2015). "Anti-Gender" mobilisational discourse of conservative and far right parties as a challenge for progressive politics. E. Kováts ve M. Poim (Ed.), Gender as symbolic glue: The position and role of conservative and far right parties in the anti-gender mobilizations in Europe içinde (ss.126-131). Budapest: Foundation for European Progressive Studies ve Friedrich-Ebert-Stiftung.

Pető, A. (2016). How are anti-gender movements changing gender studies as a profession?. Religion \& Gender, 6(2), 297-299.

Ramazanoğlu, C. (1998). Feminizm ve ezilmenin çelişkileri (M. Bayatlı, Çev.). İstanbul: Pencere Yayınları.

Resmi Gazete (2012). Milletlerarası Sözleşme (Kadınlara Yönelik Şiddet ve Aile İçi Şiddetin Önlenmesi ve Bunlarla Mücadeleye İlişkin Avrupa Konseyi Sözleşmesi). Karar sayıs1 2012/2816 https://www.resmigazete.gov.tr/eskiler/2012/03/20120308M1-1.pdf (Erişim Tarihi: 10.05 .2020$)$.

Saadet Partisi (2019). İstanbul Sözleşmesi Feshedilmeli. http://saadet.org.tr/istanbul-sozlesmesifeshedilmeli/ (Erişim Tarihi: 11.05.2020).

SETA (2019). LGBTIQ+ Talks: How to respond to the anti-gender movement?. https://seta.fi/tapahtumat/lgbtiq-talks-how-to-respond-to-the-anti-gender-movement/ (Erişim Tarihi: 10.05.2020). 
Sexuality Policy Watch (2018). Judith Butler attacked in Brazil: A briefing. https://sxpolitics.org/judith-butler-in-brazil-a-briefing/17916_(Erişim Tarihi: 10.05.2020).

Silva, I. O. P. (2017). Gender, politics and religion in protest against Judith Butler. NEXO Jornal. https://www.nexojornal.com.br/ensaio/2017/G\%C3\%AAnero-pol\%C3\%ADtica-ereligi\%C3\%A3o-nos-protestos-contra-Judith-Butler (Erişim Tarihi: 10.05.2020).

Squire, I. (2018). Gender ideology and the Istanbul Convention in Bulgaria. Bulgaria.

Stoller, R. J. (1968). Sex and gender. London: Hogarth Press.

Stone, A. (2016). Feminist felsefeye giriş (Y. Cingöz, B. Tanrısever, Çev.). İstanbul: Otonom Yayınları.

Şahin, M. ve Gültekin, M. (2013). Toplumsal cinsiyet eşitliğine dayall politika uygulayan ülkelerde kadın ve aile. İstanbul: Sekam Yayınları.

Şaşman-Kaylı, Derya (2007). Kadın bedeninin annelikle imtihanı: Toplumsal cinsiyet bakış açısının annelik kurgularlyla iliş̧kisi. D. Altun ve H. Toker (Ed.), Toplumsal cinsiyet-farklı disiplinlerden yaklaşımlar içinde (ss.61-78). Ankara: Nika Yayınları.

Şişman, N. (1996). Global konferanslarda kadın politikaları. İstanbul: İz Yayıncılık.

Şişman, N. (2013). Emanetten mülke: Kadın, beden, siyaset. İstanbul: İz Yayıncılık.

Şişman, N. (2015). Küreselleşmenin pençesi İslam’ın peçesi. İstanbul: İnsan Yayınları.

Taylor, S. E., Peplau, L. A. ve Sears, D. O. (2012). Sosyal psikoloji (Çev. Ali Dönmez). Ankara: İmge Yayınevi.

TBMM Kütüphanesi (2011). TBMM tutanak dergisi. Dönem 24, Yasama Y11ı 2, 23. Birleşim, Cilt 5.

Toprak, H. K. (2019). Asri ve hür: Tanzimat'tan Cumhuriyet'e Türkiye'de kadın kimliğinin dönüşümü. İnsan \& Toplum, 9(3),1-26.

Uluslararas1 Af Örgütü (2019). Time for change - justice for rape survivors in the nordic countries. London: Amnesty International Ltd.

University College London (2019). Stop gender! Anti-gender movements in Europe. https://www.ucl.ac.uk/ssees/events/2019/feb/stop-gender-anti-gender-movements-europe (Erişim Tarihi: 10.05.2020).

Vatican City (2019). "Male and female He created them"- Towards a path of dialogue on the question of gender theory in education. Congregation for Catholic Education (for educational institutions).

Vieten, U. M. (2018). Review of anti-gender campaigns in Europe: Mobilising against equality. Feminist Dissent, 3, 257-264.

Wilkinson, A. (2017). Latin America's gender ideology explosion. Anthrophology News, 58 (2).

Yıldırım, S. (2018). Hak, cinayet ve politika üçgeninde kürtaj hakkı. Sosyal ve Beşeri Bilimler Araştırmaları Dergisi Kadın Çalışmaları Özel Sayısı, 19/42.

\section{ETİK ve BİLİMSEL İLKELER SORUMLULUK BEYANI}

$\mathrm{Bu}$ çalışmanın tüm hazırlanma süreçlerinde etik kurallara ve bilimsel atıf gösterme ilkelerine riayet edildiğini yazar(lar) beyan eder. Aksi bir durumun tespiti halinde Afyon Kocatepe Üniversitesi Sosyal Bilimler Dergisi'nin hiçbir sorumluluğu olmayıp, tüm sorumluluk makale yazarlarına aittir. 